\title{
Effect of milk source and stabilizers on the compositional and sensorial quality of yoghurt
}

\author{
Aijaz Hussain Soomro ${ }^{1 *}$, Abdul Ghani Dars ${ }^{1}$, Saghir Ahmed Sheikh ${ }^{1}$, \\ Shahzor Gul Khaskheli ${ }^{1}$, Abdul Samad Magsi ${ }^{2}$, Aasia Akbar Panhwar ${ }^{1}$ \\ and Aisha Talpur ${ }^{2}$ \\ 1. Institute of Food Sciences and Technology, Faculty of Crop Production Sindh Agriculture University-Pakistan \\ 2. Department of Animal Products Technology, Faculty of Animal Husbandry and Veterinary Sciences Sindh \\ Agriculture University-Pakistan \\ *Corresponding author's email: aijaz68@ hotmail.com \\ Citation \\ Aijaz Hussain Soomro, Abdul Ghani Dars, Saghir Ahmed Sheikh, Shahzor Gul Khaskheli, Abdul Samad Magsi, \\ Aasia Akbar Panhwar and Aisha Talpur. Effect of milk source and stabilizers on the compositional and sensorial \\ quality of yoghurt. Pure and Applied Biology. Vol. 5, Issue 4, pp1316-1322. \\ http://dx.doi.org/10.19045/bspab.2016.50158
}

Received: $16 / 08 / 2016$

Revised: $30 / 11 / 2016$

Accepted: 04/12/2016

Online First: 09/12/2016

\section{Abstract}

The study was carried out to evaluate the effect of milk source and stabilizers on the compositional and sensorial quality of yoghurt. The buffalo and cow milk was used as milk source, gelatin and pectin used at a concentration of $0.2 \%$ as stabilizer to prepare the yoghurt. Results showed that the fat, protein content, titratable acidity and Total solids of buffalo milk yoghurt was higher $6.70 \%, 4.46 \%, 0.88 \%$ and $16.50 \%$ respectively, than the cow milk yoghurt $5.90 \%, 4.43 \%, 0.73 \%$ and $14.00 \%$. Non-significant $(\mathrm{P}>0.05)$ different were found in both types of yoghurt with the addition of pectin and gelatin. While total solids content was significantly $(\mathrm{P}<0.05)$ increased in buffalo milk yoghurt with pectin $17.43 \%$ and gelatin $16.83 \%$. Whereas, $\mathrm{pH}$ of yoghurt with addition of pectin and gelatin was 4.60 and 4.58, respectively, as compared to the cow milk yoghurt showed 4.85 and 4.59. Further, it was found that the syneresis in control cow milk yoghurt was higher $(6.76 \mathrm{ml} / 2 \mathrm{~h})$ than control buffalo milk yoghurt $(5.32 \mathrm{ml} / 2 \mathrm{~h})$. Sensory analysis showed that buffalo milk yoghurt with gelatin ranked higher in score for body/texture,flavor and overall acceptability. The study concluded that better quality yoghurt can be prepared from buffalo milk with the addition of $0.2 \%$ gelatin as stabilizer.

Keywords: Yoghurt; Buffalo milk; Cow milk; Hydrocolloids; Gelatin; Pectin; Syneresis

Introduction thermophilic lactic acid bacteria Yoghurt has been used for centuries in diets, with time yoghurt has been constantly modified to get a product with improved appearance and nutritional effects. Yoghurt is a dairy product obtained by controlled fermentation of milk by selected

Streptococcus thermophilus and
Lactobacillus delbrueckii subsp. bulgaricus. These organisms are used as yoghurt cultures to produce a lactic flavor and yoghurt aroma [1]. As compared to milk, yoghurt has better nutritive value. The 
complex protein fractions of milk are changed in much simpler form in yoghurt, which can easily be digested and assimilated by the body. Free fatty acids and vitamin B contents increase significantly during yoghurt making. Likewise yoghurt is also rich in essential and non-essential amino acids [2]. Yoghurt is very popular owing to a variety of health claims and healing values, the flavor of yoghurt has also played a significant role in increasing its consumer demand, therefore sweeteners (sugar, honey and aspartame), flavorings (vanilla), fruits and stabilizers are added to improve the textural properties. The aroma, body, and taste of yoghurt and other cultured dairy products can vary depending on the type of culture and milk, quantity of milk fat and nonfat milk solids, fermentation process, and temperature used.

The physical attributes of yoghurt, with the lack of visual whey separation and perceived viscosity, are vital aspects for overall sensory consumer acceptance and quality. An understanding of the mechanisms involved in the texture development and the effect of processing conditions on texture development may help to improve the quality of yoghurt. Whey separation or syneresis is the major problem in commercial yoghurt. The quality of yoghurt can be improved with the use of different stabilizers by protective colloid properties [3]. These substances prevent separation of various ingredients, increased the viscosity, texture, creaminess and mouth feel also help to prevent separation of whey from yoghurt. The stabilizers are classified as natural gums such as pectin, synthetically produced carboxyl methyl cellulose, plant origin corn starch and gelatin from animal source. During yoghurt preparation these stabilizers are used to overcome the problem of syneresis and to enhance the desired texture and stability during processing and storage.
Gelatin stabilizer is a translucent brittle solid hydrocolloid, colourless or a little yellow and produced by partial hydrolysis of collagen from connective tissues of animals. Gelatin stabilizer contains 98 - 99\% protein however it has less nutritional value. It is high in non-essential amino acids glycine, proline although deficient in essential amino acids such as lysine, thryptophan [4]. The importance of gelatin as a stabilizer does not related to its nutritive value but in its properties as a protective hydrocolloid used to modify physical properties of foods. Pectin a polymeric carbohydrate is another stabilizer which has a high molecular weight and form gel under suitable condition. Keeping in view the importance of the subject this study was designed to evaluate the effect of milk source and stabilizers on the quality of yoghurt.

\section{Materials and methods \\ Buffalo and cow milk}

The study was conducted to evaluate the effect of milk source and stabilizers on the compositional and sensorial quality of yoghurt. The buffalo and cow milk was purchased from dairy farms in vicinity of Tandojam and brought to the laboratory of Institute of Food Sciences and Technology, Faculty of Crop Production, Sindh Agriculture University, TandoJam. Buffalo milk was coded as BM and cow milk as CM, and strained through a muslin cloth. Gelatinand pectin (Food grade) was used in concentration of $0.1,0.2$ and $0.4 \%$ in milk to produce yoghurt in preliminary study. On the basis of sensory evaluation more acceptable concentration $(0.2 \%)$ of each gelatin and pectin was further used in the study.

\section{Yoghurt preparation}

Yoghurt was produced from buffalo and cow milk according to the method as described by Tamime and Robinson (2007) with slight modification, the buffalo and cow milk was divided into three parts and 
coded with $\mathrm{BMC}, \mathrm{BMP}$ and $\mathrm{BMG}$ and CMC, CMP and CMG codes, respectively. All the samples coded with BMP, CMP and BMG, CMG were added pectin and gelatin, respectively with concentration of $0.2 \%$, whereas, control yoghurt samples coded as $\mathrm{BMC}$ and $\mathrm{CMC}$ were prepared without addition of stabilizers. After that the milk sample were heated at $90^{\circ} \mathrm{C}$ for $10 \mathrm{~min}$ and cooled to $45^{\circ} \mathrm{C}$. Then these were inoculated with $3.0 \%$ starter culture and incubated at $42^{\circ} \mathrm{C}$ till $\mathrm{pH}$ decreased to desired level. The experiment was replicated in triplicate with each in duplicate batches.

\section{Analysis of yoghurt}

The $\mathrm{pH}$, titratable acidity percentage, total solids content and ash was analyzed according to the method as described by [5]. Gerber method was used to determine the fat content as described by [6]. Protein content was determined according to the method of British Standards Institution [7]. Lactose content was determined by difference method.

\section{Extent of serum separation (syneresis)}

Serum separation of yoghurt was evaluated using a drainage test as method described by [8]. Yoghurt sample (20g) was placed on mesh $(0.4 \mathrm{~mm})$ and kept in refrigerator at 5$8^{\circ} \mathrm{Cfor}$ two hours. The drained liquid was measured and expressed as $\mathrm{ml} / 2 \mathrm{~h}$.

\section{Sensory evaluation}

Sensory attributes of different types of yoghurts were evaluated according to the hedonic scale as reported by [9].

\section{Statistical analysis}

The obtained data was statistically analyzed by using computerized statistical package i.e. Student Edition of Statistix, Version 8.1 (copyright 2005, Analytical Software, USA).

\section{Results}

The study was conducted to find out the Effect of Milk Source and Stabilizers on the Compositional and Sensorial Quality of
Yoghurt. The result showed that the mean $\mathrm{pH}$ of control cow milk yoghurt was higher $(4.85 \%)$ then buffalo milk control yoghurt $(4.61 \%)$ followed by buffalo milk yoghurt with gelatin and pectin $4.60 \%, 4.58 \%$, respectively, a non-significant difference $(\mathrm{P}>0.05)$ was found among all these treatments. Results indicate that the titratable acidity of buffalo milk yoghurt with gelatin was higher $0.88 \%$ then with pectin $0.80 \%$. While, the titratable acidity of yoghurt prepared from cow milk with pectin and gelatin was 0.78 and $0.77 \%$, respectively which were slightly lower than the control $0.73 \%$ (Table 1).The results showed $17.43 \%$ total solids of buffalo milk yoghurt with pectin followed by gelatin $16.83 \%$, and control sample $16.50 \%$. The average lactose content (Table1)in the control cow milk yoghurt showed $2.73 \%$ which slightly higher followed by buffalo milk yoghurt with pectin $2.70 \%$. However, the difference among the mean for lactose content in all types of yoghurt was statistically non-significant $(\mathrm{P}>0.05)$. The results for the fat content (Table1)of control yoghurt prepared from buffalo milk showed $6.70 \%$ and with addition of stabilizers pectin and gelatin showed 6.66 and $6.67 \%$ respectively, which was slightly higher than the control cow milk yoghurt 5.90\%. The results of protein showed $4.46 \%$ in control buffalo milk yoghurt followed by with pectin and gelatin $4.36 \%$ and $4.33 \%$. Further statistical analysis revealed that the protein content of all types of yoghurt was found to be statistically similar $(\mathrm{P}>0.05)$. The results of different samples of syneresis (serum separation) illustrated in Table1 revealed that the syneresis of control yoghurt (buffalo and cow $)$ was higher $(\mathrm{P}<0.05)$ i.e. 5.32 and $6.76 \mathrm{ml} / 2 \mathrm{~h}$, respectively. However, the yoghurt produced from both milk with gelatin and pectin was observed lower $(\mathrm{P}>0.05)$. 
Table 1. Effect of stabilizers on the compositional quality of buffalo and cow milk yoghurt

\begin{tabular}{|l|l|l|l|l|l|l|l|}
\hline \multirow{2}{*}{ Characteristics } & \multicolumn{5}{|c|}{ Treatments } & LSD \\
& BMC & BMP & BMG & CMC & CMP & CMG & SE \\
\hline $\mathrm{pH}$ & $4.61^{\mathrm{a}}$ & $4.60^{\mathrm{a}}$ & $4.58^{\mathrm{a}}$ & $4.85^{\mathrm{a}}$ & $4.59^{\mathrm{a}}$ & $4.59^{\mathrm{a}}$ & $0.1335 \pm 0.061$ \\
\hline Titratable acidity \% & $0.76^{\mathrm{a}}$ & $0.80^{\mathrm{a}}$ & $0.88^{\mathrm{a}}$ & $0.73^{\mathrm{a}}$ & $0.78^{\mathrm{a}}$ & $0.77^{\mathrm{a}}$ & $0.1699 \pm 0.078$ \\
\hline Total solids \% & $16.50^{\mathrm{abc}}$ & $17.43^{\mathrm{a}}$ & $16.83^{\mathrm{ab}}$ & $15.0^{\mathrm{cd}}$ & $15.0^{\mathrm{d}}$ & $16.0^{\mathrm{bcd}}$ & $1.1552 \pm 0.530$ \\
\hline Lactose \% & $2.55^{\mathrm{a}}$ & $2.70^{\mathrm{a}}$ & $2.63^{\mathrm{a}}$ & $2.73^{\mathrm{a}}$ & $2.53^{\mathrm{a}}$ & $2.46^{\mathrm{a}}$ & $0.395 \pm 0.1813$ \\
\hline Fat \% & $6.70^{\mathrm{a}}$ & $6.66^{\mathrm{a}}$ & $6.67^{\mathrm{a}}$ & $5.90^{\mathrm{a}}$ & $5.80^{\mathrm{a}}$ & $5.80^{\mathrm{a}}$ & $1.3066 \pm 0.599$ \\
\hline Protein \% & $4.46^{\mathrm{a}}$ & $4.36^{\mathrm{a}}$ & $4.33^{\mathrm{a}}$ & $4.43^{\mathrm{a}}$ & $4.23^{\mathrm{a}}$ & $4.33^{\mathrm{a}}$ & $0.3248 \pm 0.149$ \\
\hline Ash \% & $1.33^{\mathrm{a}}$ & $1.26^{\mathrm{ab}}$ & $1.30^{\mathrm{a}}$ & $1.13^{\mathrm{ab}}$ & $1.13^{\mathrm{ab}}$ & $1.06^{\mathrm{b}}$ & $0.2011 \pm 0.092$ \\
\hline Syneresis (ml/2hr) & $5.32^{\mathrm{b}}$ & $3.93^{\mathrm{c}}$ & $2.18^{\mathrm{d}}$ & $6.76^{\mathrm{a}}$ & $4.42^{\mathrm{bc}}$ & $2.75^{\mathrm{d}}$ & $0.9027 \pm 0.414$ \\
\hline
\end{tabular}

Values with different superscripts within same row are significantly different $(\mathrm{P}<0.05)$

\section{Sensory analysis}

The score rated by panel of judges for sensorial parameters of yoghurt prepared with stabilizers (gelatin and pectin) is presented in Table 2. It was observed that the both types of control yoghurt received lower score (i.e. 5.44 and 4.99, respectively) than the yoghurt of both types with pectin (6.55 and 6.33, respectively) and with gelatin (6.11 and 5.99, respectively). The flavor score (Table 2) indicated that control buffalo milk yoghurt ranked (26.55), whereas with pectin and gelatin ranked 29.77 and 31.00. Whereas, the score received by cow milk yoghurt prepared with pectin was 25.00 , it was statistically similar (P>0.05) to all types of yoghurt. The buffalo milk yoghurt with pectin and gelatin perceived higher score (24.77 and 26.25, respectively) than the control (21.55). However, statistically the all types of yoghurt were similar $(\mathrm{P}>0.05)$ to each other. The score for overall acceptability indicated that buffalo milk yoghurt with gelatin received higher score 31.88 as compared to buffalo milk yoghurt with pectin 30.55 and control29.99. However, the cow milk yoghurt with gelatin recorded 22.99 score as compared to control 23.55 .

Table 2. Effect of stabilizers on the sensory quality (score) of buffalo and cow milk yoghurt

\begin{tabular}{|l|l|l|l|l|}
\hline \multicolumn{1}{|c|}{ Treatments } & Appearance & Flavor & Texture & $\begin{array}{l}\text { Overall } \\
\text { acceptability }\end{array}$ \\
\hline $\begin{array}{l}\text { Buffalo milk yoghurt control } \\
\text { (BMC) }\end{array}$ & $5.44 \mathrm{a}$ & $26.55 \mathrm{a}$ & $21.55 \mathrm{a}$ & $29.99 \mathrm{abc}$ \\
\hline $\begin{array}{l}\text { Buffalo milk yoghurt with } \\
\text { pectin (BMP) }\end{array}$ & $6.55 \mathrm{a}$ & $29.77 \mathrm{a}$ & $24.33 \mathrm{a}$ & $30.55 \mathrm{ab}$ \\
\hline $\begin{array}{l}\text { Buffalo milk yoghurt with } \\
\text { gelatin (BMG) }\end{array}$ & $6.11 \mathrm{a}$ & $31.00 \mathrm{a}$ & $26.25 \mathrm{a}$ & $31.88 \mathrm{a}$ \\
\hline $\begin{array}{l}\text { Cow milk yoghurt control } \\
\text { (CMC) }\end{array}$ & $4.99 \mathrm{a}$ & $19.88 \mathrm{~b}$ & $19.88 \mathrm{a}$ & $23.55 \mathrm{bc}$ \\
\hline $\begin{array}{l}\text { Cow milk yoghurt with pectin } \\
\text { (CMP) }\end{array}$ & $6.33 \mathrm{a}$ & $25.00 \mathrm{ab}$ & $22.77 \mathrm{a}$ & $23.22 \mathrm{c}$ \\
\hline $\begin{array}{l}\text { Cow milk yoghurt with gelatin } \\
\text { (CMG) }\end{array}$ & $5.99 \mathrm{a}$ & $30.44 \mathrm{a}$ & $21.55 \mathrm{a}$ & $24.99 \mathrm{abc}$ \\
\hline LSD (0.05) SE \pm & $1.6924 \pm 0.776$ & $6.339 \pm 2.905$ & $6.5259 \pm 2.995$ & $7.0514 \pm 3.236$ \\
\hline
\end{tabular}

Values with different letters within same columns are significantly different $(\mathrm{P}<0.05)$ from each other 


\section{Discussion}

The pectin or gelatin stabilizers are often added to the milk base to improve the appropriate yoghurt properties such as appearance, texture, mouth feel and consistency to prevent the whey separation (wheying-off) [2]. The stabilizers may help in providing a more homogeneous consistency and lessen batch to batch variation. Therefore, it was observed in the present study that buffalo milk proved significantly better for the preparation of quality yoghurt due to its higher fat and total solids content, whereas, cow milk ranked second in preparation of quality yoghurt. The $\mathrm{pH}$ of yoghurt with and without stabilizers found non-significant $(\mathrm{P}>0.05)$. Similar observations were recorded by [10] they used seven stabilizers and reported that except corn starch other stabilizers have not any significant effect on the $\mathrm{pH}$. The reason for decrease in the $\mathrm{pH}$ was increase in acidity. The results obtained are similar to the findings of [11, 12] who reported decrease in the $\mathrm{pH}$ value of the yoghurt during storage. This study further confirmed that there was no significant variation in acidity values due to addition of stabilizer. According to [13] yoghurt samples prepared with or without addition of pectin and gelatin did not show any appreciable difference in their final acidity. Subsequent studies on yoghurt did not show any significant effect on biochemical performance of the starter with added gelatin. Further, it was stated that the effect of various additives revealed enhanced acidity in yoghurt. This finding is in accordance with the $[13,14]$ standard, the minimum titratable acidity of yoghurt was recorded Similar results was recorded by [15] in plain yoghurt. Moreover, further study by [16] observed that the acidity in plain yoghurt ranged from 0.31 to 1.35 per cent. Total solids content in yoghurt was slight increase produced with pectin and gelatin however results are in agreement with the result of [17] who reported that addition of stabilizers has insignificant effect on the total solids content of yoghurt made from cow milk. Whereas the protein contents were significant amongst stabilizers. This may be associated to the small proportions of the stabilizers used. The gelatin could be attributed to the less dilution effect to its being a nitrogen source of animal origin [18]. As milk and its fermented derivative, yoghurt, are wellknown sources of high quality dietary proteins with higher biological value. The lactose content decreased in treated yoghurt might be due the breakdown of lactose to lactic acid by the action of lactic acid bacteria. The results are in supported with the conclusion of [10]. It was also found that use of gelatin in the yoghurt as stabilizer has significantly reduced the extent of syneresis $(P<0.05)$. Similarly, [20] also observed that the use of gelatin at $0.2-0.3$ percent levels improves the quality of yoghurt with reduced syneresis. This might be due to effective immobilization of the aqueous phase by the gelatin in the yoghurt network which thus significantly reduced the susceptibility to syneresis [21, 22]. It is worth noting that large amounts of gelatin would induce the formation of a gel network with the sodium caseinate in the yogurt mixture [23]. Besides the effect of total solids content [24] studies suggest a specific association between yoghurt fat content and syneresis [25]. Besides this high amounts of inoculated micro-organisms and high incubation temperature also resulted in high syneresis $[24,26]$. The higher fat content in the milk matrix is important for strengthening the structural network formed by caseins during the fermentation process, as it contributes to higher viscosity in yoghurt with higher concentration of buffalo milk. Another relevant fact is that gel formation is closely linked to protein 
rearrangement, especially casein, which in turn depends on the type of milk used, because types of casein vary in different types of milk [27]. The results for appearance revealed that there was no significant change in the score for appearance due to the addition of stabilizer. This indicated that the variation in the score for appearance of yoghurt due to different levels of stabilizer was not greatly influenced by the inclusion of stabilizers. These results are further supported by [28] that good quality yoghurt has a gel like coagulation and with porcelain like surface without wheying off. It has natural milk colour and fresh appearance.

The good quality yoghurt has pleasant milky to slightly sour taste with natural yoghurt flavor. The results revealed that the variation in the score for flavor due to different treatments was significant. The data regarding average indicating that flavor of all the samples was good irrespective of treatments. The characteristic flavor of yoghurt is due to production of lactic acid, acetaldehyde and other carbonyl compounds during fermentation of lactose by yoghurt culture [29]. However, [20] stated that various stabilizers (gelatin, CMC, gum acacia, sodium alginate and pectin) have no adverse influence on flavor producing ability of yoghurt starters. The good quality plain yoghurt should have custard like body with a smooth texture. Adequate firmness without syneresis is essential for a top quality product. The study further showed that variation in the score for body and texture due to different treatments was found to be significant. Whereas, [30] stated that an increase in SNF in milk contribute to refinement in taste of yoghurt with improved consistency, viscosity and reduced whey separation. Gelatin levels had significant effect on body and texture of yoghurt. The use of $0.3 \%$ gelatin level resulted in best quality product with firm body and smooth texture [31]. The overall acceptability of yoghurt was determined by the judges. Hence, it is evident that highest acceptability score was recorded for yoghurt with $0.2 \%$ gelatin concentration for buffalo and cow milk yoghurt.

\section{Conclusion}

It was concluded from this study that the yoghurt prepared from buffalo milk with $0.2 \%$ gelatin as stabilizer resulted in comparatively better physico-chemical and sensory characteristics with reduced syneresis as compared to cow milk yoghurt.

\section{Authors' contributions}

Conceived, designed and performed the experiments: AG Dars \& AS Magsi, Analyzed the data: SG Khaskheli, Contributed reagents/ materials/ analysis tools: AA Panhwar \& A Talpur, Wrote the paper: SG Khaskheli \& AH Soomro.

\section{References}

1. Soomro AH, Arain MA, Khaskeli M \& Bhutto B (2003). Comparative study on the physico-chemical composition of industrial yoghurt and indigenous dahi. Online J Biol Sci 3: 86-90.

2. Tamime AY \& Robinson RK (2007). Yoghurt Science and Technology. 3rd ed. Abington, Cambridge, England: Woodhead Publishing Ltd. CRC Press. Boca Raton U.S.A. p. 791.

3. Trudso JE (1991). Hydrocolloids. In Food Additive User's Handbook. First edition. Eds J. Smith Blackie and sons Ltd. London. p. 223-235.

4. Ward AG \& Courts A (1977). The Science and Technology of Gelatin. Academic Press London. pp. 258-260

5. AOAC Dairy products (2000). In Official of Analysis association of Official Analytical Chemists Inc. Gaithersburg, U.S.A.

6. James CS (1996). Determination of fat contents of dairy products by the Gerber method. In Analytical chemistry of food. Blacki Academic and Professionals, an imprint of Chapman and Hall, Glasgow, UK. pp. 93-95.

7. BSI (1990). Determination of the nitrogen content of liquid milk. In: Method of 
Chemical Analysis of Liquid Milk and Cream. BS 1741, British Standards Institute, London, UK.

8. Dannenberg F \& Kessler HG (1988). Effect of denaturationof $\beta$-lactoglobulin on texture properties of set-style nonfat yoghurt-1.synneresis. Milchwissenschaft 43:632-635.

9. Nelson JA \& Trout GM (1981). Judging of dairy products. $4^{\text {th }}$ Ed. AVI Publishing Company Inc, Westport, Connecticut. pp. 296-297.

10. Ayub M \& Saddiq M (2003). Effect of different types of milk and stabilizers on the chemical composition of quality yoghurt. Sarhad J Agric 19(2): 271-178.

11. Radke-Mitchell LC \& Sandine WE (1986). Influence of temperature on associative growth of S.thermophilus and $L$. bulgaricus. J. Dairy Sci 69: 2558-2568.

12. Moon S, Eun KAS \& Hwa S (1993). Physicochemical properties of commercial yoghurt in Korea. J Food Sci Tech 48: 89-92.

13. Baisya RK \& Bose ANJ (1974). Food Sci and Technol 11: 70-73

14. International Dairy Federation (1969). Compositional Standard for Fermented Milks. Standard No.47

15. Laxminarayana H \& Shankar PA (1980). Fermented milk in human nutrition. Ind Dairyman 32:121-126.

16. Kosikowski FV (1981). Properties of commercial flavored frozen yoghurts. $J$ Food Prot 44(11): 853-856.

17. Mehanna NM \& Mehanna AS (1989). On the use of stabilizer for improving some properties of cows' milk yoghurt. Egy $J$ Dairy Sci 17(2): 289-296.

18. Imeson A (1999). Thickening and gelling agents for foods. $2^{\text {nd }}$ edition. Aspen Publ. Inc. Gaithersburg, Maryland.

19. Alakali JS, Okonkwo TM \& Iordye EM (2008). Effect of stabilizers on the physico-chemical and sensory attributes of thermized yoghurt. Afric. J. Biotechnol 7 (2): 158-163.

20. Gupta A \& Prasad DN (2000). Use of stabilizers in cultured milk products. Indian Dairyman 52(9): 19-24.
21. Keogh MK \& O'Kennedy BT (1998). Rheology of stirred yogurt as affected by added milk fat, protein and hydrocolloids. J. Food Sci 63(1): 108112.

22. Fiszman SM, Lluch MA \& Salvador A (1999). Effect of addition of gelatin on microstructure of acidic milk gels and yoghurt and on their rheological properties. Int Dairy J 12: 895-901.

23. Lal SND, Connor CJO' \& Eyres L (2006). Application of emulsifiers/stabilizers in dairy products of high rheology. $A d v$. Colloid Interface Sci 123-126: 433-437.

24. Varghese S \& Mishra H (2008). Modeling of acidification kinetics and textural properties in dahi (Indian yoghurt) made from buffalo milk using responsesurface methodology. Inter J Dairy Technol 61: 284-289

25. Riener J, Noci F, Cronin D, Morgan D \& Lyng J (2010). A comparison of selected quality characteristics of yoghurts prepared from thermosonicated and conventionally heated milks. Food Chem 119: 1108-1113.

26. Lucey J \& Singh H (1998). Formation and physical properties of acid milk gels: a review. Food Res Inter 30: 529-542

27. Clarck S \& Sherbon J (2000). Genetic variants of alpha s1-CN in goat milk: breed distribution and associations with milk composition and coagulation properties. Small Rum Res 38: 135- 143.

28. Ranganadham M \& Gupta SK (1987). Sensory evaluation of dahi and yoghurt. Indian Dairyman 39(10): 493-497.

29. Pette JW \& Lolkeme H (1950). Acid production and aroma formation in yogurt. Neth. Milk Dairy J 4: 261-273.

30. Chawla AK \& Balachandran R (1994).Studies on yoghurt buffalo milk: effect on different solids not fat content on chemical, rheological and sensory characteristics. Indian J Dairy Sci 47(9): 762-765.

31. Kanake UJ, Joshi SV \& Chavan KD (2009). Effect of skim milk powder and gelatin on chemical composition and sensory quality of yoghurt. J. Dairying Foods Home Sci 28(1): 1-7. 